\title{
Assessing dental students' professional training satisfaction with operative dentistry teaching and curriculum: A study in Saudi Arabia.
}

Mohammed Alqarni ( $\square$ maalqarny@kku.edu.sa )

\section{Research article}

Keywords: Curriculum, Dental students, Operative Dentistry, Professional training satisfaction

Posted Date: August 3rd, 2020

DOI: https://doi.org/10.21203/rs.3.rs-37016/v2

License: (a) (i) This work is licensed under a Creative Commons Attribution 4.0 International License. Read Full License

Version of Record: A version of this preprint was published at Medicine on June 25th, 2021. See the published version at https://doi.org/10.1097/MD.0000000000026459. 


\section{Abstract}

\section{Background}

Evaluating students' professional training satisfaction of operative dentistry teaching and curriculum can help identify their educational needs and improve the quality of the education imparted. This study aimed to assess the professional training satisfaction derived by senior undergraduate dental students in Saudi Arabia from the operative dentistry course teaching and its curriculum at different levels and among gender.

\section{Methods}

A total of 193 (109 male $56.48 \%$; and 84 female $43.52 \%$ ) students participated in a survey. The respondents were at the 10 th, 11 th, and 12 th levels of the Operative Dentistry course in a ratio of $34.2 \%$, $32.1 \%$, and $33.7 \%$, respectively. Data were collected from survey items (18 questions) covering six areas: Learning Objectives, Course Materials, Content Relevance, Instructor knowledge, Instructor delivery and Style, and Facility and environment. Descriptive and analytical tests were performed using SPSS Software 19, with the significance level set at 0.05 .

\section{Results}

A high level of satisfaction was seen among Level 10 (68.18\%), Level 11 (79.03\%), and Level 12 (86.15\%) students. A significant statistical difference was observed among Level 10 students with a low-level of satisfaction and a high level of satisfaction $(p<0.05)$. The percentage of satisfaction increased with the level. A high level of satisfaction was seen among male (78.90\%) and female (76.19\%) students, with a total satisfaction level of $77.72 \%$.

\section{Conclusion}

Continuous evaluation and assessment of teaching and curriculum can be a tool to improve the quality of education imparted, especially in clinical courses such as operative dentistry. This helps to prepare the students for their professional life as healthcare providers. The role of teaching skills related to amalgam has to be reevaluated. It is recommended to include student representation and participation in course development committees as they are the final recipients of the educational process.

\section{Background}

Any training program needs evaluation for quality assurance, and further improvement. ${ }^{1}$ Kirkpatrick's model of evaluation proposes four increasing levels to assess the impact of training programs. Level one (reaction) measures how the person feels about a course; level two (learning) measures the extent to which principles, facts, and techniques have been understood and absorbed; level three (behavior) measures the application of the principles and techniques acquired on the job; and level four (results) measures the ends, goals, and results desired. ${ }^{1,2}$ Monitoring students' reaction to their learning 
experiences is increasingly being undertaken by higher education institutions. ${ }^{3}$ This initial level of evaluation should be an inherent feature of every training program because it indicates how a training program can be enhanced and further developed besides building the base for higher levels of evaluation since reactions serve as a pointer to whether learning is possible. ${ }^{1,2}$ Students' satisfaction with and attitudes toward training programs are the most common indicators used to assess the reaction. ${ }^{1,3}$ However, there is additional value in exploring graduates' reactions to training programs because they are less emotionally attached to the institution and are back at their workplaces where they can judge whether the knowledge and skills acquired during the program match their job requirements and responsibilities.

The undergraduate dental curriculum "should prepare graduates to enter practice" ${ }^{4}$ The course's primary aim is to help students with their career expectations and develop their identity as a professional workforce. The secondary aim is to teach skills that students can use when applying for a job. ${ }^{5}$ Satisfaction and attitude are two indicators that help determine education quality. Satisfaction refers to the level to which students' experiences meet their expectations. ${ }^{6}$ However, attitudes refer to a mixture of beliefs, thoughts, and feelings that predispose graduates to respond positively or negatively toward institutions. ${ }^{7,8}$ In addition to their role in ensuring learning and teaching quality standards, the two indicators serve as a guide for students to aid their decision-making at the program/institution level and compute institutional performance indicators. ${ }^{9}$

The format of dental education varies across the world; while some institutions have a yearly system, others follow a semester system. Several factors affect the learning process in any course, such as the nature of the student him/herself, the quality of demonstrators and teachers, exposure to course materials, laboratory, and clinical facilities, and so on. Continuous evaluation of these factors is necessary to ascertain whether the conditions are conducive to learning in the program assessed.

Operative dentistry is an essential branch of dentistry constituting a significant part of the teaching process in dental colleges. Students are introduced to operative dentistry from level 4 , and this continues until level 12. There has been continuous development in the field of operative dentistry, both in terms of materials and equipment and techniques. The students attend various continuing dental education programs conducted by national dental organizations and professional societies during their course, where they are exposed to newer materials, techniques, and various treatment protocols. Added to this, the availability of this information is also on social media and other various online platforms. Thus, the present generation of students has a high level of awareness and expectations. Hence, in the present scenario, it is imperative to evaluate the students' level of satisfaction and to correlate and implement the findings to develop the course. The operative dentistry course teaching in the dental school undergoes a review every semester, and improvements are suggested and implemented to keep students abreast of the latest. It is vital to analyze and understand whether the changes made to the course achieve the intended goals. As with all the recent developments, continuous assessment of teaching strategy is necessary for a comprehensive evaluation of the teaching program. 
One of the methods for evaluating an educational system is surveying student opinions because students experience the teaching's full effect during the course. ${ }^{10}$ As the primary recipients of the educational system, evaluating student satisfaction in the professional training is one of the significant components of assessing and improving the quality and delivery of education. ${ }^{11,12}$ Many studies have been reported regarding dental students' satisfaction, perception, attitude and career motivations in general. ${ }^{13,14,15,16,17}$ The learning process is different for each individual; even in the same educational environment, learning may not occur in all students at a similar level and quality. ${ }^{18}$ This difference may be attributed to students' different backgrounds, strengths, weaknesses, interests, ambitions, levels of motivation, and approaches to studying. ${ }^{19}$ Student satisfaction definitions have been interpreted widely in different ways. Elliott and Healy defined student satisfaction as a "short-term attitude resulting from an evaluation of a student's educational experience" and claimed that student satisfaction was achieved when their actual experiences or performances met or exceeded their initial expectations. ${ }^{20}$ Aldridge and Rowley divided student satisfaction evaluations into two categories, focusing on classroom teaching and learning evaluation and the second being focused on the comprehensive student experience. ${ }^{21}$ Bryant and Bodfish claimed that student satisfaction was a significant performance indicator for higher education institutions, with many universities implementing rigorous quality assurance processes. ${ }^{22}$ Most colleges measure student satisfaction by administering student satisfaction surveys such as CIRP (Freshmen Survey), NSSE (National Survey of Student Engagement), SSI (Student Strength Inventory), and Noel Levitz survey. As student satisfaction has often been linked to student persistence, such surveys give administrators valuable insights into how the institution's quality is perceived by the different stakeholders, assisting in institutional strategic planning and goal setting. ${ }^{23} \mathrm{~A}$ study conducted in a dental college in Saudi Arabia in 2020 concluded that the teaching staff and students' satisfaction levels with the curriculum were significantly associated with their perception that the curriculum produces competent graduates. ${ }^{24}$ Many studies have reported on the students' opinion, assessment, perception, and satisfaction of dental education in general and in subjects such as oral surgery, periodontics, and prosthodontics. ${ }^{25,26,27,28}$ No study has been reported on the satisfaction of operative dentistry teaching and curriculum in particular. This study sought to gain a greater insight since operative dentistry forms a significant bulk of dental education. This study aimed to evaluate the professional training satisfaction levels of senior undergraduate students training in operative dentistry regarding the teaching and the curriculum at different levels and among gender.

\section{Methods}

This descriptive-analytic study was conducted on level 10, level 11, and level 12 (clinical level) students in the academic year 2019-20. Ethical clearance for this study was obtained from the Institutional Review Board of King Khalid University College of Dentistry. The questionnaire distributed among the students consisted of six domains: Learning objectives, Course materials, Content relevance, Instructor knowledge, Instructor delivery and style, and Facility and environment. A total of 193 students participated in the survey, of which 109 (56.48\%) were male, and 84 (43.52\%) were female students. The respondents were 
students in levels 10,11 , and 12 of the courses and were in the ratio of $34.2 \%, 32.1 \%$, and $33.7 \%$, respectively. Participation in the study was voluntary, and the students were briefed regarding the study and the questionnaire. The original questionnaire was developed by RAND staff, based on J Kirkpatrick,

to evaluate the Adult Learning Principles and Training Evaluation. ${ }^{29}$ The questionnaire used in this study was slightly modified from the original to make it compatible for operative dentistry teaching in dental education. The responses were graded 3, 2, or 1 corresponding to Agree, Somewhat Agree, or Disagree. After the questionnaires were collected, the data were entered into SPSS 19.0 (Inc., Chicago, III., USA); Descriptive and analytical tests were used to evaluate the professional training satisfaction level with education offered at different levels and between genders in operative dentistry teaching and curriculum.

\section{Results}

The results for all the six domains showed no statistical difference in responses in terms of gender $(p>0.05)$ (see Table 1). Likewise, no statistical difference in responses was seen between the levels ( $p>0.05$ ), except for Q2 in the Learning domain (see Table 2). It was observed that the percentage of respondents with disagreement was higher to Q2 in the Learning domain as compared to the other domains among the three levels. The average total score for all questionnaire domains and comparison between genders showed that mean scores for each domain are closer to the maximum scores, respectively. Furthermore, there was no statistically significant difference in the average satisfaction scores between genders ( $p>0.05$ ). (see Table 3 ). The overall results for total satisfaction and its dimensions show there that there is no statistically significant difference in average satisfaction scores among student levels ( $p>0.05$ ). However, in the Learning domain, level 10 respondents had significantly lower total satisfaction average scores than scores of respondents in other levels $(p<0.05)$. (Table 4$)$. The association between levels of satisfaction (High and Low) based on demographic profile showed statistically significant differences among the three levels $(10,11$, and 12$)$, but no difference was seen in terms of the gender of the students. ( $p>0.05)$ (Table 5).

\section{Discussion}

Students at three different levels of the operative dentistry course in Saudi Arabia were participants of this survey on their professional training satisfaction regarding the course's teaching and curriculum. These students had already undergone preclinical training and were into clinical training. Clinical-based education is a multi-factorial process wherein the students implement the theoretical knowledge they gain in preclinical training on patients. Dentistry is an essential field of medical science, and hence, enhancing the quality of clinical dental education improves people's oral/dental health.

In the Kingdom of Saudi Arabia, most colleges follow the semester-type curriculum. Each year has two semesters, each comprising fourteen weeks of actual teaching and four weeks of practical/clinical and final theory exams. Operative dentistry starts from level 4 of the dental course. Level 4 to level 6 are primarily preclinical courses where the students are introduced to the materials they will be using and work in simulated laboratories learning different cavity design preparations and restorations with 
different restorative materials. Level 4 course is primarily involved in introducing the students to the instruments and the materials. Level 5 course is wholly dedicated to amalgam cavity preparations and restorations, whereas level 6 involves composite cavity preparations and restorations. In addition to these, they have E-Learning assignments on the recent advances in material sciences and techniques. Levels 10, 11, and 12 involve students implementing their skills on patients under their supervisors' direct supervision. The curriculum in Level 10 requires the students to work with amalgam restorations on patients compulsorily. Level 11 and 12 students work with composite cavity preparations and restorations and are also trained in esthetic restorations.

Modern education for women in the Arab world is considered recent in its history. In countries like Saudi Arabia, modern education for women is a 20th-century event. ${ }^{30,31}$ The universities in Saudi Arabia admit male and female students, but they have different campuses.

During their professional training, the male students treat male patients, and the female students treat female patients at their respective campuses. Parahoo et al. investigated whether gender was a factor in measuring overall student satisfaction in Universities in the Gulf region. ${ }^{32}$ It was found that the two genders displayed a difference in the factors influencing their satisfaction. A study in 2017 investigated the potential barriers for the professional development of women dentists in Saudi Arabia and suggested recommendations to minimize the effects of these barriers. ${ }^{33}$ Hence in the present study, the level of professional training satisfaction between male and female students was also investigated.

Each course has its learning objectives specified and described at the beginning of the course. During the first lecture, the learning objectives are explained to the students, and the same is evaluated at the end of the semester by testing whether students have obtained the requisite knowledge and skills consistent with the learning objectives and are clear about what is expected of them. In the current study, it was observed that the respondents agreed that most of the Learning objectives were met during the course except the question regarding knowledge and skills (Tables 1 and 2). Level 10 students whose skills are primarily based on Amalgam cavity preparations and restorations had a statistical difference, which was significant $(p>0.05)$. The role of amalgam in operative dentistry today is being debated. The level of awareness of the present generation of students makes them question the need to learn a skill that they might not practice in their professional careers.

During the course, the students are exposed to various teaching materials and strategies such as lectures, powerpoint presentations, and assessment criteria such as quizzes, online assignments, and continuous evaluation of their preclinical work/clinical work. These need to be evaluated and assessed to understand whether they are consistent with the learning objectives to achieve the intended goal. The results of this study indicated that all the three items under the Course Material domain showed that neither the level nor the gender led to any statistical difference in responses ( $p>0.05)$ (Tables 1 and 2).

After training, it is critical to understand the implications of how the student applies his training as a dentist in society. The learning process aims to produce an independent thinking dentist who will be able 
to apply the necessary knowledge and skills using his or her rationale to be a successful dentist. The relevance of the course is reflected when the intended goals are achieved. This study's results have indicated that most respondents agreed that the course training increased their level of confidence to work as an independent dentist. All three items under the Course Relevance domain showed no statistical difference in responses regardless of gender or level $(p>0.05)$. A majority of the respondents $(>88 \%)$ agreed that the course was relevant, as seen from the training (Tables 1 and 2 ).

Instructors play an essential role in shaping the attitude and enthusiasm of the students. The instructor's knowledge and skills, along with his or her experience, is a vital component of the teaching process, especially in clinical sciences. Students often get influenced and motivated by the instructor. The students are exposed to a fixed group of instructors on a rotational basis during the semester. In the Kingdom of Saudi Arabia, as of now, most of the universities have teachers from various parts of the world who have been trained in their own countries. The teachers undergo continuous orientation programs of the university to update, understand, and comply with the teaching and assessment pattern. A study evaluated the satisfaction rate of clinical dentistry students with clinical teaching in Kermanshah University of Medical Sciences between 2015 and 2016. ${ }^{34}$ They stated that maximum cooperation of the professors and accurate implementation of the educational curriculum could have a significant effect on increasing student satisfaction. It is essential to understand the instructors' impact on professional training satisfaction at different levels and between gender. This study showed that most of the respondents $(>80 \%)$ had a favorable opinion about the role of instructors. There was no statistical difference seen in terms of gender or level ( $p>0.05$ ) (Tables 1 and 2$)$.

Since operative dentistry is a clinical subject, the importance of the clinical facilities and the environment must be emphasized. The clinical setup, the availability of the latest materials, and the instruments and their utilization during the clinical training period play a vital role in students' education. Most respondents in this study agreed $(>90 \%)$ that the operative dentistry clinics' Facility and conduciveness were satisfactory. There was no statistical difference based on gender or level ( $p>0.05)$ (Tables 1 and 2$)$. However, it is interesting to note that satisfaction was more significant at a higher level of the students.

Analyzing the association between the levels of satisfaction from the perspective of gender and level, it was interesting to observe that there was a statistical difference in terms of the level of students (Table 5). The two levels of satisfaction (low and high) were made based on mean scores. If the scores are less than or equal to mean, it is considered a low level, and the scores are above the mean it is considered a high level. Level 10 students recorded a lower level of satisfaction (31.82\%), whereas levels 11 and 12 recorded a high level of satisfaction (68.18\%). Level 10 students are the junior-most level of the students among the respondents. The amount of exposure to the professional field is less as compared to the higher level of students. The clinical work the level 10 students perform under supervision on the patients is more basic as compared to levels 11 and 12. Level 10 students have to compulsory perform a certain number of amalgam cavity preparations and restorations during their clinical training. The students' attitude towards amalgam restorations and the difficulty to convince the patients to undergo treatment with amalgam have been documented. ${ }^{35,36}$ This factor may have resulted in a lower level of satisfaction 
among the level 10 students ( $p>0.05$ ) (Table 5). There was no statistical difference in the gender group ( $p>0.05$ ) (Table 5). However, it is interesting to observe that the level of satisfaction increased in students' higher level, indicating a greater level of professional training satisfaction.

Dentistry is a clinical major in which adequate skills and training are highly crucial in graduate students' performance, promoting oral and dental health systems. Because the educational system, equipment available, performance of tutors, availability of clinical material, and the students' expectations might be different in dental schools, the results of this study may not be generalized to other dental schools. This study did not assess the reasons for shortcomings in professional training as it was not in the purview of this study. This could be another limitation of the present study.

\section{Conclusions}

This study focused primarily on operative dentistry teaching and the relevance of the present curriculum offered in the Kingdom of Saudi Arabia. Feedback and satisfaction of students would be an essential tool in assessing and improving education. The study findings show that most students of Levels 10, 11, and 12 were satisfied with the teaching and operative dentistry curriculum. However, regarding the skills obtained during the course, the question arises whether the need to teach the principles of amalgam cavity preparation and restoration, which the students might not utilize at all in their professional career, is still valid. Reevaluation of the curriculum, focusing on the present and future needs, or limiting the amalgam exercises to preclinical training may be suggested. This will give the students more time to practice clinical setup skills, which will help them professionally. The level of satisfaction was also observed to be higher at the higher levels of the course. None the less this study provides an insight for policymakers for the future to improve upon. To achieve higher levels of satisfaction, it is recommended to set up course development committees with effective student representation and participation to fill up the lacunae that might be present regarding professional training. With rapid innovation in terms of materials and techniques in operative dentistry, the curriculum needs to be updated and continuously assessed by students to understand their satisfaction as they are the final recipients of the educational process and the future of healthcare in any nation.

\section{Declarations}

Ethics approval and consent to participate: Ethical clearance for this study was obtained from the Institutional Review Board of King Khalid University College of Dentistry, Approval No IRB/KKUCOD/ETH/2019-20/012 dated 25/12/2019. Informed written consent was obtained from all the participants of the questionnaire study.

Consent for publication: Not applicable.

Competing interests: The author declares that there are no competing interests. 
Availability of data and materials: The datasets during and/or analyzed during the current study available from the corresponding author on reasonable request.

Funding: Nil.

Author Contributions: MAA has contributed to the conception of the work, has drafted the work, and in preparing and writing the manuscript. MAA has read and approved the manuscript.

Acknowledgments: The author would like to thank Dr. S B Javali for the statistical analysis and Dr. Shashit Shetty Bavabeedu to help acquire the data. The author would also like to thank all the dental students who participated in the study.

Author Information: Mohammed Al Qarni has completed his Board Certification and Specialty Certificate in Restorative Dentistry from SCHS, Riyadh, Saudi Arabia, in 2012. He completed his Master of Clinical Restorative and Esthetic Dentistry from Pacific University, CA, USA \& accordingly gained his Diplomate of MFDRCSI, Dublin, Ireland, in 2014. He is currently working as an Associate Professor in the Department of Restorative Dental Sciences, King Khalid University College of Dentistry, Abha, and Director of Saudi Board of Restorative Dentistry Training Centers at Southern Region, Saudi Arabia.

\section{References}

1. Kirkpatrick D. Techniques for Evaluating Training Programs. Revisiting Kirkpatrick's Four-Level Model. Training and Development, 1996;50 (1):54-7.

2. Kirkpatrick DL, Kirkpatrick JD. Implementing the Four Levels: A Practical Guide for Effective Evaluation of Training Programs. San Francisco, CA: Berrett-Koehler Publishers; 2007.

3. El Ansari W, Moseley L. You get what you measure: Assessing and reporting student satisfaction with their health and social care educational experience. Nurse Educ Today 2011;31(2):173-178.

4. Macy Study T, Formicola AJ, Bailit HL, Beazoglou TJ, Tedesco LA. Introduction to the Macy study report. J Dent Educ. 2008;72(2 Suppl):5-9

5. Szabó, R.M., Davis, J.M. \& Antal, M. Introducing career skills for dental students as an undergraduate course at the University of Szeged, Hungary. BMC Med Educ 20, 68 (2020). https://doi.org/10.1186/s12909-020-1981-4

6. Wiers-Jenssen J, Stensaker B, Grogaard JB. Student satisfaction: Towards an empirical deconstruction of the concept. Qual Higher Educ 2002; 8:183-195.

7. Brown G, Manogue M, Rohlin M. Assessing attitudes in dental education: Is it worthwhile? Br Dent J 2002;193(12):703-707.

8. Divaris K, Barlow PJ, Chendea SA, Cheong WS, Dounis A, Dragan IF, et al. The academic environment: the students' perspective. Eur J Dent Educ 2008;12 Suppl 1:120-130.

9. Shepard LA. The role of assessment in a learning culture. Educ Res 2000;29(7):4-14. 
10. Pariseau SE, McDaniel JR. Assessing service quality in schools of business. Int J Qual Reliabil Manag 1997;14(3):204-218.

11. Henzi D, Davis E, Jasinevicius R, Hendricson W. In the students' own words: What are the strengths and weaknesses of the dental school curriculum? J Dent Educ 2007;71(5):632-645.

12. Youngson C, Fox K, Boyle E, Blundell K, Baker R. Improving the quality of clinical teaching in a restorative clinic using student feedback. Eur J Dent Educ. 2008;12(2):75-79. doi:10.1111/j.16000579.2007.00486.x

13. Al-Surimi K, AlAyadi H, Salam M. Female dental students' perceptions of patient safety culture: a cross sectional study at a middle eastern setting. BMC Med Educ. 2018 Dec 10;18(1):301. doi: 10.1186/s12909-018-1415-8. PMID: 30526570; PMCID: PMC6288871.

14. Fita S, Alshuraim F, Almulhim A, AlHumaid J, Alhareky M, Nazir M. Possible Future Career Challenges and Associated Factors among Dental Students and Interns. Int J Dent. 2020 Apr 9;2020:9730125. doi: 10.1155/2020/9730125. PMID: 32351570; PMCID: PMC7171615.

15. Elsheikh NMA, Osman IMA, Husain NE, Abdalrahman SMA, Nour HEYM, Khalil AA, Awadalla H, Ahmed MH. Final year dental students' perception and practice of professionalism and ethical attitude in ten Sudanese dental schools: A cross-sectional survey. J Family Med Prim Care. 2020 Jan 28;9(1):87-92. doi: 10.4103/jfmpc.jfmpc_499_19. PMID: 32110571; PMCID: PMC7014902.

16. Adebayo ET, Oginni FO, Aborisade AO, Fomete B. PROFESSIONAL EXPERIENCES, TRAINING ATTITUDES AND EXPECTATIONS OF RESIDENTS IN DENTISTRY: A NATIONWIDE SURVEY. J West Afr Coll Surg. 2017 Oct-Dec;7(4):85-119. PMID: 30479993; PMCID: PMC6237314.

17. Knevel RJ, Gussy MG, Farmer J, Karimi L. Nepalese dental hygiene and dental students' career choice motivation and plans after graduation: a descriptive cross-sectional comparison. BMC Med Educ. 2015 Dec 11;15:219. doi: 10.1186/s12909-015-0500-5. PMID: 26655045; PMCID: PMC4676855.

18. Saban A. Ögrenme-Ögretme Süreci Yeni Teori ve Yaklasimlar. Ankara: Nobel; 2005.

19. Felder RM, Brent R. Understanding student differences. J Eng Educ. 2005;94(Suppl 1):57-72.

20. Kevin M. Elliott \& Margaret A. Healy. Key Factors Influencing Student Satisfaction Related to Recruitment and Retention, Journal of Marketing for Higher Education, 2001 10:4, 1-11.

21. Aldridge S. \& Rowley J. Measuring customer satisfaction in higher education. Quality Assurance in Education, 6(4), pp. 197-204.

22. Bryant and S. Bodfish, "The relationship of student satisfaction to key indicators for colleges and universities," 2014 National Research Report, Noel-Levitz, Inc., Cedar Rapids, IA, USA, 2014.

23. Al-Sheeb, B.; Hamouda, A.M.; Abdella, G.M. Investigating determinants of student satisfaction in the first year of college in a public university in the state of Qatar. Educ. Res.Int.2018,2018,1-14.

24. Abdelsalam M, Rodriguez TE, Brallier L. Student and Faculty Satisfaction with Their Dental Curriculum in a Dental College in Saudi Arabia. Int J Dent. 2020; 2020:6839717. Published 2020 Apr 8. doi:10.1155/2020/6839717 
25. Field JC, Walmsley AD, Paganelli C, et al. The Graduating European Dentist: Contemporaneous Methods of Teaching, Learning and Assessment in Dental Undergraduate Education. Eur J Dent Educ. 2017;21 Suppl 1:28-35. doi:10.1111/eje.12312

26. Burdurlu MÇ, Cabbar F, Dağaşan V, et al. A city-wide survey of dental students' opinions on undergraduate oral surgery teaching. Eur J Dent Educ. 2020 May;24(2):351-360. DOI: 10.1111/eje.12506.

27. Gürsoy M, Wilensky A, Claffey N, et al. Periodontal education and assessment in the undergraduate dental curriculum-A questionnaire-based survey in European countries. Eur J Dent Educ. 2018;22(3):e488-e499. doi:10.1111/eje.12330

28. Sampaio-Fernandes M, Dutra M, Oliveira SJ, Reis-Campos JC, Azevedo Á, Figueiral MH. Students' self-confidence and perceived quality of prosthodontics education: A study in the Faculty of Dental Medicine of the University of Porto. Eur J Dent Educ. 2020;24(3):559-571. doi:10.1111/eje.12537

29. Greenfield V, Shelton S, Balkovich E, Davis J, Adamson D. Adult learning principles and training evaluation. Appendix F. In: The Federal Voting Assistance Program and the Road Ahead: Achieving Institutional Change through Analysis and Collaboration. Santa Monica, CA: RAND Corporation; 2015:171-186.

30. Shaker RE, Babgi AA. Women in dentistry: A perspective on major universities in Saudi Arabia. Part 1: historical background. Saudi Dent J. 2009;21(3):103-6.

31. Shaker RE, Babgi AA. Women in dentistry: A perspective on major universities in Saudi Arabia. Part 2: Analysis and statistical data. Saudi Dent J. 2009;21(3):107-112.

32. Parahoo SK, Harvey HL \& Tamim RM. Factors influencing student satisfaction in universities in the Gulf region: Does gender of students' matter? Journal of Marketing for Higher Education, 2013, vol 23, no 2, 135-154.

33. Rajeh M, Nicolau B, Pluye P, Qutob A, Esfandiari S. Are There Barriers for Professional Development of Women Dentists? A Qualitative Study in Saudi Arabia. JDR Clin Trans Res. 2017;2(2):119-131. doi:10.1177/2380084416685083

34. Soltani E, Amiri S M, Moradi A. Evaluation of Dentistry Students' Satisfaction Rate with Educational Services at Kermanshah University of Medical Sciences, Iran (2015 - 16), Educ Res Med Sci. 2018; $7(1)$.

35. Rey R, Nimmo S, Childs GS, Behar-Horenstein LS. Curriculum time compared to clinical procedures in amalgam and composite posterior restorations in U.S. dental schools: a preliminary study. J Dent Educ. 2015;79:331-336.

36. Pani SC, Al Abbassi MF, Al Saffan AD, Al Sumait MA, Shakir AN. Factors influencing Saudi dental students' preference of amalgam or composite for posterior dental restorations Saudi J Oral Sci. 2014;1:30-6.

\section{Tables}


Table 1. Comparison of item responses of male and female students on the scale 


\begin{tabular}{|c|c|c|c|c|c|c|c|c|c|}
\hline Variables & Items & Male & $\%$ & Female & $\%$ & Total & $\%$ & $c^{2}$ & p-value \\
\hline \multirow[t]{12}{*}{ Learning objectives } & \multicolumn{9}{|c|}{ Q1 I have understood the learning objectives of the operative course. } \\
\hline & Disagree & 0 & 0.00 & 0 & 0.00 & 0 & 0.00 & 0.0620 & 0.8030 \\
\hline & Somewhat agree & 21 & 19.27 & 15 & 17.86 & 36 & 18.65 & & \\
\hline & Agree & 88 & 80.73 & 69 & 82.14 & 157 & 81.35 & & \\
\hline & \multicolumn{9}{|c|}{ Q2 I have gained knowledge and skills consistent with the learning objectives. } \\
\hline & Disagree & 7 & 6.42 & 4 & 4.76 & 11 & 5.70 & 0.2440 & 0.8850 \\
\hline & Somewhat agree & 18 & 16.51 & 14 & 16.67 & 32 & 16.58 & & \\
\hline & Agree & 84 & 77.06 & 66 & 78.57 & 150 & 77.72 & & \\
\hline & \multicolumn{9}{|c|}{ Q3 This course has clarified my role as a student. } \\
\hline & Disagree & 0 & 0.00 & 0 & 0.00 & 0 & 0.00 & 0.0390 & 0.8430 \\
\hline & Somewhat agree & 7 & 6.42 & 6 & 7.14 & 13 & 6.74 & & \\
\hline & Agree & 102 & 93.58 & 78 & 92.86 & 180 & 93.26 & & \\
\hline \multirow[t]{12}{*}{ Course materials } & \multicolumn{9}{|c|}{ Q1 The course materials (slides, lectures, assignments, quiz, etc.) are easy to follow. } \\
\hline & Disagree & 5 & 4.59 & 3 & 3.57 & 8 & 4.15 & 0.1240 & 0.9400 \\
\hline & Somewhat agree & 14 & 12.84 & 11 & 13.10 & 25 & 12.95 & & \\
\hline & Agree & 90 & 82.57 & 70 & 83.33 & 160 & 82.90 & & \\
\hline & \multicolumn{9}{|c|}{ Q2 The complexity and level of detail of the materials are appropriate. } \\
\hline & Disagree & 2 & 1.83 & 0 & 0.00 & 2 & 1.04 & 1.5580 & 0.4590 \\
\hline & Somewhat agree & 5 & 4.59 & 4 & 4.76 & 9 & 4.66 & & \\
\hline & Agree & 102 & 93.58 & 80 & 95.24 & 182 & 94.30 & & \\
\hline & \multicolumn{9}{|c|}{$\begin{array}{l}\text { Q3 The course materials, including resources, are essential to my success in operative } \\
\text { dentistry }\end{array}$} \\
\hline & Disagree & 6 & 5.50 & 3 & 3.57 & 9 & 4.66 & 0.5750 & 0.7500 \\
\hline & Disagree & 8 & 7.34 & 5 & 5.95 & 13 & 6.74 & & \\
\hline & Somewhat agree & 95 & 87.16 & 76 & 90.48 & 171 & 88.60 & & \\
\hline \multirow[t]{12}{*}{ Content relevance } & \multicolumn{9}{|c|}{ Q1 I shall be able to apply what I learned during this course in future as a dentist. } \\
\hline & Disagree & 0 & 0.00 & 0 & 0.00 & 0 & 0.00 & 1.5570 & 0.2120 \\
\hline & Somewhat agree & 2 & 1.83 & 0 & 0.00 & 2 & 1.04 & & \\
\hline & Agree & 107 & 98.17 & 84 & 100.0 & 191 & 98.96 & & \\
\hline & \multicolumn{9}{|c|}{ Q2 I have obtained the necessary knowledge and skills to become a successful dentist. } \\
\hline & Disagree & 2 & 1.83 & 0 & 0.00 & 2 & 1.04 & 1.5580 & 0.4590 \\
\hline & Somewhat agree & 5 & 4.59 & 4 & 4.76 & 9 & 4.66 & & \\
\hline & Agree & 102 & 93.58 & 80 & 95.24 & 182 & 94.30 & & \\
\hline & \multicolumn{9}{|c|}{ Q3 I know where to find answers to questions that may arise in my role as a dentist. } \\
\hline & Disagree & 7 & 6.42 & 3 & 3.57 & 10 & 5.18 & 0.9760 & 0.6140 \\
\hline & Somewhat agree & 8 & 7.34 & 5 & 5.95 & 13 & 6.74 & & \\
\hline & Agree & 94 & 86.24 & 76 & 90.48 & 170 & 88.08 & & \\
\hline Instructor knowledge & \multicolumn{9}{|c|}{ Q1 My learning was enriched by the instructor's knowledge. } \\
\hline
\end{tabular}


Instructor delivery and style
Facility and environment

\begin{tabular}{|l|c|c|c|c|c|c|c|c|} 
Disagree & 4 & 3.67 & 2 & 2.38 & 6 & 3.11 & 0.2650 & 0.8760 \\
\hline Somewhat agree & 4 & 3.67 & 3 & 3.57 & 7 & 3.63 & & \\
\hline Agree & 101 & 92.66 & 79 & 94.05 & 180 & 93.26 & & \\
\hline
\end{tabular}

Q2 My learning was enriched by the experience of the instructor and the examples shared in the class.

\begin{tabular}{|l|c|c|c|c|c|c|c|c|}
\hline Disagree & 5 & 4.59 & 2 & 2.38 & 7 & 3.63 & 1.2280 & 0.5410 \\
\hline Somewhat agree & 7 & 6.42 & 8 & 9.52 & 15 & 7.77 & & \\
\hline Agree & 97 & 88.99 & 74 & 88.10 & 171 & 88.60 & & \\
\hline
\end{tabular}

Q1 I was well engaged during the operative course.

\begin{tabular}{|l|c|c|c|c|c|c|c|c|}
\hline Disagree & 5 & 4.59 & 3 & 3.57 & 8 & 4.15 & 0.3250 & 0.8500 \\
\hline Somewhat agree & 6 & 5.50 & 6 & 7.14 & 12 & 6.22 & & \\
\hline Agree & 98 & 89.91 & 75 & 89.29 & 173 & 89.64 & & \\
\hline
\end{tabular}

Q2 I found it easy to be actively involved during the learning process.

\begin{tabular}{|l|c|c|c|c|c|c|c|c|}
\hline Disagree & 5 & 4.59 & 3 & 3.57 & 8 & 4.15 & 0.1230 & 0.9400 \\
\hline Somewhat agree & 9 & 8.26 & 7 & 8.33 & 16 & 8.29 & & \\
\hline Agree & 95 & 87.16 & 74 & 88.10 & 169 & 87.56 & & \\
\hline
\end{tabular}

Q3 I had ample opportunity to ask questions and receive answers.

\begin{tabular}{|l|c|c|c|c|c|c|c|c|}
\hline Disagree & 2 & 1.83 & 2 & 2.38 & 4 & 2.07 & 0.0740 & 0.9640 \\
\hline Somewhat agree & 5 & 4.59 & 4 & 4.76 & 9 & 4.66 & & \\
\hline Agree & 102 & 93.58 & 78 & 92.86 & 180 & 93.26 & & \\
\hline
\end{tabular}

Q4 I had ample opportunity to practice and demonstrate the skills that I leant.

\begin{tabular}{|l|c|c|c|c|c|c|c|c|}
\hline Disagree & 6 & 5.50 & 9 & 10.71 & 15 & 7.77 & 1.7970 & 0.4070 \\
\hline Somewhat agree & 7 & 6.42 & 5 & 5.95 & 12 & 6.22 & & \\
\hline Agree & 96 & 88.07 & 70 & 83.33 & 166 & 86.01 & & \\
\hline
\end{tabular}

Q5 I was comfortable with the pace of the operative sessions in the course.

\begin{tabular}{|l|c|c|c|c|c|c|c|c|}
\hline Disagree & 7 & 6.42 & 9 & 10.71 & 16 & 8.29 & 1.1630 & 0.5590 \\
\hline Somewhat agree & 9 & 8.26 & 7 & 8.33 & 16 & 8.29 & & \\
\hline Agree & 93 & 85.32 & 68 & 80.95 & 161 & 83.42 & & \\
\hline
\end{tabular}

Q6 I was comfortable with the length of the operative sessions in the course.

\begin{tabular}{|l|c|c|c|c|c|c|c|c|}
\hline Disagree & 9 & 8.26 & 8 & 9.52 & 17 & 8.81 & 0.2450 & 0.8850 \\
\hline Somewhat agree & 11 & 10.09 & 7 & 8.33 & 18 & 9.33 & & \\
\hline Agree & 89 & 81.65 & 69 & 82.14 & 158 & 81.87 & & \\
\hline
\end{tabular}

Q1 I found the operative laboratory and the operative clinic free of distractions and conducive to study

\begin{tabular}{|l|c|c|c|c|c|c|c|c|}
\hline Disagree & 1 & 0.92 & 0 & 0.00 & 1 & 0.52 & 0.8040 & 0.6690 \\
\hline Somewhat agree & 3 & 2.75 & 2 & 2.38 & 5 & 2.59 & & \\
\hline Agree & 105 & 96.33 & 82 & 97.62 & 187 & 96.89 & & \\
\hline Total & 109 & 100.0 & 84 & 100.0 & 193 & 100.0 & & \\
\hline
\end{tabular}


Page 15/20 


\begin{tabular}{|c|c|c|c|c|c|c|c|c|c|}
\hline Variables & Items & $\begin{array}{l}10^{\text {th }} \\
\text { level }\end{array}$ & $\%$ & $\begin{array}{l}11^{\text {th }} \\
\text { level }\end{array}$ & $\%$ & $\begin{array}{l}12^{\text {th }} \\
\text { level }\end{array}$ & $\%$ & $c^{2}$ & $\begin{array}{c}\mathrm{p}- \\
\text { value }\end{array}$ \\
\hline \multirow[t]{12}{*}{ Learning objectives } & \multicolumn{9}{|c|}{ Q1 I have understood the learning objectives of operative course. } \\
\hline & Disagree & 0 & 0.00 & $\overline{0}$ & 0.00 & 0 & 0.00 & 4.0150 & 0.1340 \\
\hline & $\begin{array}{l}\text { Somewhat } \\
\text { agree }\end{array}$ & 15 & 22.73 & 14 & 22.58 & 7 & 10.77 & & \\
\hline & Agree & 51 & 77.27 & 48 & 77.42 & 58 & 89.23 & & \\
\hline & \multicolumn{9}{|c|}{ Q2 I have gained knowledge and skills consistent with the learning objectives. } \\
\hline & Disagree & 9 & 13.64 & 1 & 1.61 & 1 & 1.54 & 13.6640 & $.008 *$ \\
\hline & $\begin{array}{l}\text { Somewhat } \\
\text { agree }\end{array}$ & 11 & 16.67 & 13 & 20.97 & 8 & 12.31 & & \\
\hline & Agree & 46 & 69.70 & 48 & 77.42 & 56 & 86.15 & & \\
\hline & \multicolumn{9}{|c|}{ Q3 The course has clarified my role as a student. } \\
\hline & Disagree & 0 & 0.00 & 0 & 0.00 & 0 & 0.00 & 2.9670 & 0.2270 \\
\hline & $\begin{array}{l}\text { Somewhat } \\
\text { agree }\end{array}$ & 7 & 10.61 & 4 & 6.45 & 2 & 3.08 & & \\
\hline & Agree & 59 & 89.39 & 58 & 93.55 & 63 & 96.92 & & \\
\hline \multirow[t]{12}{*}{ Course materials } & \multicolumn{9}{|c|}{ Q1 The course materials (slides, lectures, assignments, quiz, etc.) are easy to follow. } \\
\hline & Disagree & 5 & 7.58 & 2 & 3.23 & 1 & 1.54 & 6.9370 & 0.1390 \\
\hline & $\begin{array}{l}\text { Somewhat } \\
\text { agree }\end{array}$ & 12 & 18.18 & 8 & 12.90 & 5 & 7.69 & & \\
\hline & Agree & 49 & 74.24 & 52 & 83.87 & 59 & 90.77 & & \\
\hline & \multicolumn{9}{|c|}{ Q2 The complexity and level of detail of the materials are appropriate. } \\
\hline & Disagree & 0 & 0.00 & 2 & 3.23 & 0 & 0.00 & 4.9420 & 0.2930 \\
\hline & $\begin{array}{l}\text { Somewhat } \\
\text { agree }\end{array}$ & 4 & 6.06 & 3 & 4.84 & 2 & 3.08 & & \\
\hline & Agree & 62 & 93.94 & 57 & 91.94 & 63 & 96.92 & & \\
\hline & \multicolumn{9}{|c|}{$\begin{array}{l}\text { Q3 The course materials, including resources, are essential to my success in operative } \\
\text { dentistry }\end{array}$} \\
\hline & Disagree & 5 & 7.58 & 2 & 3.23 & 2 & 3.08 & 7.0210 & 0.1350 \\
\hline & Disagree & 8 & 12.12 & 2 & 3.23 & 3 & 4.62 & & \\
\hline & $\begin{array}{l}\text { Somewhat } \\
\text { agree }\end{array}$ & 53 & 80.30 & 58 & 93.55 & 60 & 92.31 & & \\
\hline \multirow[t]{10}{*}{ Content relevance } & \multicolumn{9}{|c|}{ Q1 I shall be able to apply what I learned during this course in the future as a dentist. } \\
\hline & Disagree & 0 & 0.00 & 0 & 0.00 & 0 & 0.00 & 1.0290 & 0.5980 \\
\hline & $\begin{array}{l}\text { Somewhat } \\
\text { agree }\end{array}$ & 1 & 1.52 & 1 & 1.61 & 0 & 0.00 & & \\
\hline & Agree & 65 & 98.48 & 61 & 98.39 & 65 & 100.0 & & \\
\hline & \multicolumn{9}{|c|}{ Q2 I have obtained the necessary knowledge and skills to become a successful dentist. } \\
\hline & Disagree & 1 & 1.52 & 1 & 1.61 & 0 & 0.00 & 1.0380 & 0.9040 \\
\hline & $\begin{array}{l}\text { Somewhat } \\
\text { agree }\end{array}$ & 3 & 4.55 & 3 & 4.84 & 3 & 4.62 & & \\
\hline & Agree & 62 & 93.94 & 58 & 93.55 & 62 & 95.38 & & \\
\hline & \multicolumn{9}{|c|}{ Q3 I know where to find answers to the questions that may arise in my role as a dentist. } \\
\hline & Disagree & 4 & 6.06 & 4 & 6.45 & 2 & 3.08 & 3.3830 & 0.4960 \\
\hline
\end{tabular}




\begin{tabular}{|c|c|c|c|c|c|c|c|c|c|}
\hline \multirow{3}{*}{$\begin{array}{l}\text { Instructor knowledge } \\
\text {. }\end{array}$} & $\begin{array}{l}\text { Somewhat } \\
\text { agree }\end{array}$ & 7 & 10.61 & 3 & 4.84 & 3 & 4.62 & & \\
\hline & Agree & 55 & 83.33 & 55 & 88.71 & 60 & 92.31 & & \\
\hline & \multicolumn{9}{|c|}{ Q1 My learning was enriched by the instructor's knowledge. } \\
\hline & Disagree & 2 & 3.03 & 3 & 4.84 & 1 & 1.54 & 1.3970 & 0.8450 \\
\hline & $\begin{array}{l}\text { Somewhat } \\
\text { agree }\end{array}$ & 3 & 4.55 & 2 & 3.23 & 2 & 3.08 & & \\
\hline & Agree & 61 & 92.42 & 57 & 91.94 & 62 & 95.38 & & \\
\hline & \multicolumn{9}{|c|}{$\begin{array}{l}\text { Q2 My learning was enriched by the experience of the instructor and the examples shared } \\
\text { in the class. }\end{array}$} \\
\hline & Disagree & 4 & 6.06 & 2 & 3.23 & 1 & 1.54 & 2.2680 & 0.6870 \\
\hline & $\begin{array}{l}\text { Somewhat } \\
\text { agree }\end{array}$ & 5 & 7.58 & 4 & 6.45 & 6 & 9.23 & & \\
\hline & Agree & 57 & 86.36 & 56 & 90.32 & 58 & 89.23 & & \\
\hline \multirow{24}{*}{$\begin{array}{l}\text { Instructor delivery } \\
\text { and style }\end{array}$} & \multicolumn{9}{|c|}{ Q1 I was well engaged during the operative course. } \\
\hline & Disagree & 5 & 7.58 & 1 & 1.61 & 2 & 3.08 & 5.3830 & 0.2500 \\
\hline & $\begin{array}{l}\text { Somewhat } \\
\text { agree }\end{array}$ & 6 & 9.09 & 4 & 6.45 & 2 & 3.08 & & \\
\hline & Agree & 55 & 83.33 & 57 & 91.94 & 61 & 93.85 & & \\
\hline & \multicolumn{9}{|c|}{ Q2 I found it easy to be actively involved in the learning process of the operative course. } \\
\hline & Disagree & 5 & 7.58 & 1 & 1.61 & 2 & 3.08 & 5.8610 & 0.2100 \\
\hline & $\begin{array}{l}\text { Somewhat } \\
\text { agree }\end{array}$ & 8 & 12.12 & 5 & 8.06 & 3 & 4.62 & & \\
\hline & Agree & 53 & 80.30 & 56 & 90.32 & 60 & 92.31 & & \\
\hline & \multicolumn{9}{|c|}{ Q3 I had ample opportunity to ask questions and receive answers during my course. } \\
\hline & Disagree & 3 & 4.55 & 1 & 1.61 & 0 & 0.00 & 4.0700 & 0.3970 \\
\hline & $\begin{array}{l}\text { Somewhat } \\
\text { agree }\end{array}$ & 4 & 6.06 & 2 & 3.23 & 3 & 4.62 & & \\
\hline & Agree & 59 & 89.39 & 59 & 95.16 & 62 & 95.38 & & \\
\hline & \multicolumn{9}{|c|}{ Q4 I had ample opportunity to practice and demonstrate skills that I had learnt. } \\
\hline & Disagree & 7 & 10.61 & 3 & 4.84 & 5 & 7.69 & 3.1090 & 0.5400 \\
\hline & $\begin{array}{l}\text { Somewhat } \\
\text { agree }\end{array}$ & 6 & 9.09 & 3 & 4.84 & 3 & 4.62 & & \\
\hline & Agree & 53 & 80.30 & 56 & 90.32 & 57 & 87.69 & & \\
\hline & \multicolumn{9}{|c|}{ Q5 I was comfortable with the pace of the operative sessions in the course. } \\
\hline & Disagree & 9 & 13.64 & 3 & 4.84 & 4 & 6.15 & 6.7850 & 0.1480 \\
\hline & $\begin{array}{l}\text { Somewhat } \\
\text { agree }\end{array}$ & 8 & 12.12 & 5 & 8.06 & 3 & 4.62 & & \\
\hline & Agree & 49 & 74.24 & 54 & 87.10 & 58 & 89.23 & & \\
\hline & \multicolumn{9}{|c|}{ Q6 I was comfortable with the length of the operative sessions in the course. } \\
\hline & Disagree & 10 & 15.15 & 3 & 4.84 & 4 & 6.15 & 6.5150 & 0.1640 \\
\hline & $\begin{array}{l}\text { Somewhat } \\
\text { agree }\end{array}$ & 8 & 12.12 & 5 & 8.06 & 5 & 7.69 & & \\
\hline & Agree & 48 & 72.73 & 54 & 87.10 & 56 & 86.15 & & \\
\hline
\end{tabular}


Q1 I found the operative laboratory and the operative clinics free of distractions and conducive to study.

\begin{tabular}{|l|c|c|c|c|c|c|c|c|}
\hline Disagree & 1 & 1.52 & 0 & 0.00 & 0 & 0.00 & 3.4950 & 0.4790 \\
\hline $\begin{array}{l}\text { Somewhat } \\
\text { agree }\end{array}$ & 3 & 4.55 & 1 & 1.61 & 1 & 1.54 & & \\
\hline Agree & 62 & 93.94 & 61 & 98.39 & 64 & 98.46 & & \\
\hline Total & 66 & 100.0 & 62 & 100.0 & 65 & 100.0 & & \\
\hline
\end{tabular}

Table 2. Comparison of item responses on the scale based on level $* \mathrm{p}<0.05$

Table 3. Comparison of total satisfaction and its dimensions based on gender by MannWhitney U test

\begin{tabular}{|c|c|c|c|c|c|c|}
\hline Components & Summary & Male & Female & Total & Z-value & $\mathrm{P}$-value \\
\hline \multirow{2}{*}{$\begin{array}{l}\text { Learning objectives } \\
(\text { Total score possible }=9)\end{array}$} & Mean & 8.45 & 8.49 & 8.47 & \multirow[t]{2}{*}{-0.5718} & \multirow[t]{2}{*}{0.5674} \\
\hline & SD & 1.03 & 1.08 & 1.05 & & \\
\hline \multirow{2}{*}{$\begin{array}{l}\text { Course materials } \\
\text { (Total score possible }=9 \text { ) }\end{array}$} & Mean & 8.51 & 8.62 & 8.56 & \multirow[t]{2}{*}{-0.2599} & \multirow[t]{2}{*}{0.7949} \\
\hline & SD & 1.16 & 1.02 & 1.10 & & \\
\hline \multirow{2}{*}{$\begin{array}{l}\text { Content relevance } \\
\text { (Total score possible }=9 \text { ) }\end{array}$} & Mean & 8.70 & 8.82 & 8.75 & \multirow[t]{2}{*}{-0.3938} & \multirow[t]{2}{*}{0.6937} \\
\hline & $\mathrm{SD}$ & 0.92 & 0.58 & 0.79 & & \\
\hline \multirow{2}{*}{$\begin{array}{l}\text { Instructor knowledge } \\
\text { (Total score possible }=6 \text { ) }\end{array}$} & Mean & 5.73 & 5.77 & 5.75 & \multirow[t]{2}{*}{-0.0286} & \multirow[t]{2}{*}{0.9772} \\
\hline & SD & 0.83 & 0.73 & 0.79 & & \\
\hline \multirow{2}{*}{$\begin{array}{l}\text { Instructor delivery and style } \\
(\text { Total score possible }=18 \text { ) }\end{array}$} & Mean & 16.94 & 16.76 & 16.87 & \multirow[t]{2}{*}{-0.1650} & \multirow[t]{2}{*}{0.8689} \\
\hline & SD & 2.52 & 2.65 & 2.57 & & \\
\hline \multirow{2}{*}{$\begin{array}{l}\text { Facility and environment } \\
(\text { Total score possible }=3 \text { ) }\end{array}$} & Mean & 2.95 & 2.98 & 2.96 & \multirow[t]{2}{*}{-0.1560} & \multirow[t]{2}{*}{0.8761} \\
\hline & $\mathrm{SD}$ & 0.25 & 0.15 & 0.21 & & \\
\hline \multirow{2}{*}{$\begin{array}{l}\text { Total satisfaction } \\
(\text { Total score possible }=54 \text { ) }\end{array}$} & Mean & 51.29 & 51.44 & 51.36 & \multirow[t]{2}{*}{-0.3028} & \multirow[t]{2}{*}{0.7620} \\
\hline & $\mathrm{SD}$ & 5.93 & 5.14 & 5.59 & & \\
\hline
\end{tabular}


Table 4. Comparison of total satisfaction and its dimensions by level using Kruskal-Wallis test

\begin{tabular}{|c|c|c|c|c|c|c|}
\hline Components & Summary & $10^{\text {th }}$ level & $11^{\text {th }}$ level & $12^{\text {th }}$ level & $\mathrm{H}$-value & $\mathrm{P}$-value \\
\hline \multirow{2}{*}{$\begin{array}{l}\text { Learning objectives } \\
\text { (Total score possible }=9 \text { ) }\end{array}$} & Mean & 8.23 & 8.47 & 8.71 & \multirow[t]{2}{*}{4.3690} & \multirow[t]{2}{*}{$0.0370^{*}$} \\
\hline & $\mathrm{SD}$ & 1.31 & 0.94 & 0.79 & & \\
\hline \multirow{2}{*}{$\begin{array}{l}\text { Course materials } \\
\text { (Total score possible }=9 \text { ) }\end{array}$} & Mean & 8.33 & 8.60 & 8.75 & \multirow[t]{2}{*}{0.8260} & \multirow[t]{2}{*}{0.3630} \\
\hline & $\mathrm{SD}$ & 1.29 & 1.08 & 0.85 & & \\
\hline \multirow{2}{*}{$\begin{array}{l}\text { Content relevance } \\
\text { (Total score possible }=9 \text { ) }\end{array}$} & Mean & 8.68 & 8.73 & 8.85 & \multirow[t]{2}{*}{0.1900} & \multirow[t]{2}{*}{0.6630} \\
\hline & $\mathrm{SD}$ & 0.86 & 0.91 & 0.57 & & \\
\hline \multirow{2}{*}{$\begin{array}{l}\text { Instructor knowledge } \\
\text { (Total score possible }=6 \text { ) }\end{array}$} & Mean & 5.70 & 5.74 & 5.82 & \multirow[t]{2}{*}{0.0260} & \multirow[t]{2}{*}{0.8730} \\
\hline & SD & 0.89 & 0.83 & 0.63 & & \\
\hline \multirow{2}{*}{$\begin{array}{l}\text { Instructor delivery and style } \\
\text { (Total score possible }=18 \text { ) }\end{array}$} & Mean & 16.21 & 17.23 & 17.18 & \multirow[t]{2}{*}{0.0670} & \multirow[t]{2}{*}{0.7960} \\
\hline & $\mathrm{SD}$ & 3.30 & 1.97 & 2.10 & & \\
\hline \multirow{2}{*}{$\begin{array}{l}\text { Facility and environment } \\
\text { (Total score possible }=3 \text { ) }\end{array}$} & Mean & 2.92 & 2.98 & 2.98 & \multirow[t]{2}{*}{0.0010} & \multirow[t]{2}{*}{0.9730} \\
\hline & SD & 0.32 & 0.13 & 0.12 & & \\
\hline \multirow{2}{*}{$\begin{array}{l}\text { Total satisfaction } \\
\text { (Total score possible }=54 \text { ) }\end{array}$} & Mean & 50.08 & 51.74 & 52.29 & \multirow[t]{2}{*}{3.3140} & \multirow[t]{2}{*}{0.0690} \\
\hline & SD & 7.11 & 4.62 & 4.39 & & \\
\hline
\end{tabular}

$* \mathrm{p}<0.05$ 
Table 5. Association between levels of satisfaction based on demographic profile

\begin{tabular}{|c|c|c|c|c|c|c|c|}
\hline \multirow[t]{2}{*}{ Profile } & \multicolumn{5}{|c|}{ Levels of satisfaction } & \multirow[t]{2}{*}{ c2 } & \multirow[t]{2}{*}{ p-value } \\
\hline & Low level** & $\%$ & High level*** & $\%$ & Total & & \\
\hline \multicolumn{8}{|l|}{ Level } \\
\hline Level 10 & 21 & 31.82 & 45 & 68.18 & 66 & 6.1993 & $0.0450 *$ \\
\hline Level 11 & 13 & 20.97 & 49 & 79.03 & 62 & & \\
\hline Level 12 & 9 & 13.85 & 56 & 86.15 & 65 & & \\
\hline \multicolumn{8}{|l|}{ Gender } \\
\hline Male & 23 & 21.10 & 86 & 78.90 & 109 & 0.2010 & 0.6539 \\
\hline Female & 20 & 23.81 & 64 & 76.19 & 84 & & \\
\hline Total & 43 & 22.28 & 150 & 77.72 & 193 & & \\
\hline
\end{tabular}

${ }^{*} \mathrm{p}<0.05$

** scores less than or equal to mean is considered as low level.

*** scores above the mean considered as high level.

\section{Supplementary Files}

This is a list of supplementary files associated with this preprint. Click to download.

- QuestionnaireSurveyProfessionalSatisfaction.pdf 